\title{
Microscopic Identification and Determination of Total Flavonoid Content of Moringa Leaves Extract and Ethyl Acetate Fraction (Moringa oleifera L.)
}

\author{
Annisa Fatmawati*, Depita Sucianingsih, Riza Kurniawati, Muhammad Abdurrahman \\ Department of Pharmacy, Faculty of Health Science, Universitas Alma Ata, Yogyakarta, Indonesia
}

Submitted 02 November 2021; Revised 14 December 2021; Accepted 14 December 2021; Published 30 December 2021

*Corresponding author: annisafatma20@almaata.ac.id

\begin{abstract}
This research was conducted to identify simplicia microscopically, phytochemical screening and determination of total flavonoid content of extract and ethyl acetate fraction from Moringa (Moringa oleifera L.) leaves using UV-Vis Spectrophotometry method. The experimental design used in this study was to perform microscopic identification of Moringa leaf powder simplicia, make $96 \%$ and $70 \%$ ethanol extract and ethyl acetate fraction of Moringa leaves from $70 \%$ ethanol extract, then carry out phytochemical screening and determination of total flavonoid content with quercetin standards. Phytochemical screening on the ethyl acetate fraction of Moringa leaves included tests for the content of flavonoids, saponins, tannins and alkaloids. The results of microscopic identification of Moringa leaf simplicia showed the presence of calcium oxalate crystals in the form of rosettes, mesophyll and stomata. The result of determination of total flavonoid content in $96 \%$ ethanol extract was 16.69 $\pm 0.74 \%(\mathrm{w} / \mathrm{w}), 70 \%$ ethanol extract was $10.84 \pm 0.49 \%(\mathrm{w} / \mathrm{w})$, Moringa leaf ethyl acetate fraction $14.45 \pm 0.90 \%(\mathrm{w} / \mathrm{w})$. The highest total flavonoid content was found in the $96 \%$ ethanol extract of Moringa leaves in accordance with the Indonesian Herbal Pharmacopoeia 2017, that the thick extract of Moringa leaves containing no less than $6.30 \%(\mathrm{w} / \mathrm{w})$ total flavonoids was calculated as quercetin.
\end{abstract}

Keywords: quercetin, Moringa oleifera, microscopic, flavonoid

\section{Identifikasi Mikroskopis dan Penentuan Kandungan Flavonoid Total Ekstrak Daun Kelor dan Fraksi Etil Asetat (Moringa oleifera L.)}

\begin{abstract}
Abstrak
Penelitian ini dilakukan untuk mengidentifikasi simplisia secara mikroskopis, skrining fitokimia dan penetapan kadar flavonoid total ekstrak dan fraksi etil asetat dari daun kelor (Moringa oleifera L.) dengan metode Spektrofotometri UV-Vis. Rancangan percobaan yang digunakan dalam penelitian ini dengan melakukan identifikasi mikroskopis pada simplisia serbuk daun kelor, membuat ekstrak etanol $96 \%$ dan $70 \%$ serta fraksi etil asetat daun kelor dari ekstrak etanol $70 \%$ kemudian dilakukan skrining fitokimia dan penetapan kadar flavonoid total dengan standar kuersetin. Skrining fitokimia pada fraksi etil asetat daun kelor meliputi uji kandungan flavonoid, saponin, tanin dan alkaloid. Hasil identifikasi mikroskopis simplisia daun kelor menunjukkan adanya kristal kalsium oksalat berbentuk roset, mesofil dan stomata. Hasil penetapan kadar flavonoid total pada ekstrak etanol 96\% sebesar 16,69 $\pm 0,74 \%$ (b/b), esktrak etanol 70\% sebesar 10,84 $\pm 0,49 \%(b / b)$, fraksi etil asetat daun kelor 14,45 $\pm 0,90 \%$ (b/b). Kadar flavonoid total paling besar terdapat pada ekstrak etanol $96 \%$ daun kelor sesuai dengan Farmakope Herbal Indonesia 2017, bahwa ekstrak kental daun kelor mengandung flavonoid total tidak kurang dari $6,30 \%(\mathrm{~b} / \mathrm{b})$ dihitung sebagai kuersetin.
\end{abstract}

Kata Kunci: kuersetin, Moringa oleifera, mikroskopis, flavonoid 


\section{Introduction}

Moringa plant (Moringa oleifera) is a species of the genus Moringa belonging to the family Moringaceae, which is easy to grow in tropical areas such as Indonesia. Moringa can grow in tropical and subtropical areas on all types of soil and is resistant to dry seasons within six months. Moringa leaves are widely used by the community as traditional medicine, vegetables, beauty and fatty foods. One of the benefits of Moringa leaves as beauty is as an antiaging (premature aging), moisturizing and overcoming dry skin. ${ }^{1}$ Moringa leaf extract also has antidiabetic activity $^{2}$, tyrosinase inhibitor ${ }^{3}$, antibacterial ${ }^{4}$, antioxidant, anti-inflammatory and antiarthritis. $^{5}$

Moringa leaves contain flavonoids and are rich in pro vitamins $\mathrm{A}, \mathrm{C}, \mathrm{E}$, especially carotene which will be converted into vitamin $A$ in the body and significantly affect hepatoprotective. The content of glucocyanate and isothiocyanate compounds in Moringa plants is known to the public as hypotensive, anti-cancer, inhibiting bacterial and fungal activity. ${ }^{6}$ Determination of levels and studies on the content profile of secondary metabolites of the flavonoid group can be used as the basis for determining the isolation of potential compounds as antidiabetic, antioxidant, antiaging or other compounds that can become active raw materials for drugs. ${ }^{7}$

Based on previous research, Moringa leaves contain secondary metabolites including alkaloids, flavonoids, tannins and saponins. ${ }^{9}$ Flavonoids are one of the largest natural phenolic antioxidant compounds and are found in all plants, so it can be ascertained that there are flavonoids in these plants. Phytochemical compounds in Moringa leaves that act as high antioxidant compounds are flavonoids so that the total flavonoid content in Moringa leaves can be determined using a UV-Visible spectrophotometer. ${ }^{10}$ Determination of the total flavonoid content of an extract of natural ingredients can use quercetin as a standard. Natural extracts are reacted with $\mathrm{AlCl}_{3}$ compounds and form complex compounds whose levels can be determined by visible spectrophotometry. ${ }^{10,11}$ The complex reaction between standard quercetin and $\mathrm{AlCl}_{3}$ is shown in Figure 1. This study aimed to determine the total flavonoid content in the extract and the ethyl acetate fraction of Moringa leaves. ${ }^{8}$

\section{Materials and methods}

\subsection{Materials}

The tools used in the research were microscope, maceration vessels, separating funnels, electric stoves, laboratory glassware (pyrex), digital scales, stirring rods, $10 \mathrm{ml}$ measuring pipettes, test tubes, aluminium foil, rotary evaporator, water baths, porcelain crucibles, funnels, filter paper, oven, cream containers, vortex, universal $\mathrm{pH}$, ruler, adhesive and dispersible test equipment and their weights, cuvette and UV-Vis spectrophotometer (Thermo Scientific Evolution 201). The materials used in this study included Moringa leaves (Moringa oleifera L.) from Beringharjo Market Yogyakarta, 70\% ethanol, 96\% ethanol, ethyl acetate, petroleum ether, quercetin (Sigma Aldrich), $10 \% \mathrm{AlCl}_{3}$ and 5\% acetic acid.

\subsection{Research sites}

This research was conducted at the Integrated Chemistry Laboratory and Phytochemical Laboratory, Bachelor of Pharmacy Study Program, Alma Ata University Yogyakarta in May 2021.

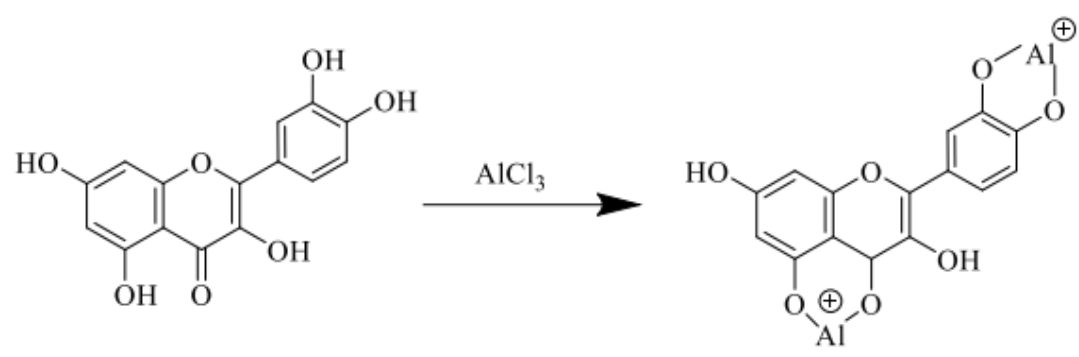

Figure 1. Complex Reaction Between Quercetin and $\mathrm{AlCl}_{3}{ }^{8}$ 
2.3. Microscopic identification of Moringa leaf simplicia

Moringa leaf powder is placed on a glass object, given a solution of chloral hydrate and covered with a cover glass. Then heated on a bunsen fire with tube clamps and kept from boiling, and heated to dry. The preparations were then placed on a microscope and observed with a magnification of 10 times. ${ }^{12,13}$

\subsection{Moringa leaf extract}

Moringa leaf powder was weighed as much as 2000 grams for $70 \%$ ethanol solvent and 500 grams for $96 \%$ solvent were put into different glass jars then added ethanol solvent according to concentration variations as much as $10 \mathrm{~L}$ for $70 \%$ ethanol solvent and $2.5 \mathrm{~L}$ for $96 \%$ ethanol to completely submerged and stored for $3 \times 24$ hours at room temperature and stirred occasionally to speed up the process of dissolving chemical compounds. The extract obtained was then filtered and separated from the residue, then the residue or dregs obtained were remaceration for $3 \times 24$ hours with the same solvent and amount (1:5). The filtrate obtained was then concentrated using a rotary evaporator at a temperature of $60^{\circ} \mathrm{C}$ until a thick brown extract was obtained. The thick extract was weighed to obtain the extract yield. $^{2}$

\subsection{Fractionation of $70 \%$ ethanolic Moringa leaf extract \\ Moringa leaf ethyl acetate fraction was} made by weighing 51.66 grams of EEDK, then dissolved using $500 \mathrm{ml}$ of distilled water and fractionated using petroleum ether (PE) and ethyl acetate in a ratio of 1:1. The ethyl acetate phase containing the moringa leaf extract fraction was evaporated using a rotary evaporator at a temperature of $60^{\circ} \mathrm{C}$ at a speed of $60 \mathrm{rpm}$. Next, the semi-viscous extract was put into a porcelain cup and evaporated over a water bath. The formula for calculating the yield of the ethyl acetate fraction of Moringa leaves is $=$ ((Weight of thick ethyl acetate fraction/Weight of thick extract of Moringa leaves) $\mathrm{x} 100 \%) .{ }^{11}$

2.6. Moringa leaf ethyl acetate fraction phytochemical screening

Phytochemical tests were carried out to determine the class of compounds contained in the ethanol extract of Moringa leaves (EEDK) and the ethyl acetate fraction (FEDK). Phytochemical examination was carried out, namely the examination of alkaloid compounds, polyphenols (tannins), flavonoids, and saponins. Polyphenol examination was carried out by taking one $\mathrm{ml}$ of EEDK added with $1 \% \mathrm{FeCl}_{3}$ reagent. The reaction is positive if a blackish or dark blue color is formed. For the examination of flavonoids by taking $1.0 \mathrm{ml}$ of EEDK, adding a few drops of $10 \% \mathrm{NaOH}$, the reaction will show a positive flavonoid if there is a specific color change. And saponin examination was carried out by adding $1.0 \mathrm{ml}$ of EEDK with hot water and shaking. Positive reaction of saponins when a long-lasting foam is formed. ${ }^{11,12}$

2.7. Determination of total flavonoid content of Moringa leaf extract and ethyl acetate fraction

2.7.1. Determination of maximum wavelength

$1.0 \mathrm{~mL}$ of quercetin solution was taken as much as $1.0 \mathrm{~mL}$ added with $1 \mathrm{~mL}$ of $10 \%$ $\mathrm{AlCl}_{3}$ and $8 \mathrm{ml}$ of $5 \%$ acetic acid, then the UV-Vis spectrophotometer readings with a wavelength of 400-500 $\mathrm{nm}$ were taken. ${ }^{10}$

\subsubsection{Determination of operating time}

Determination of operating time is done by using a $100 \mathrm{ppm}$ quercetin solution taken as much as $1 \mathrm{~mL}$ added with $1 \mathrm{~mL}$ of $10 \%$ $\mathrm{AlCl}_{3}$ and $8 \mathrm{ml}$ of $5 \%$ acetic acid, the solution obtained is measured by the absorbance of the wavelength obtained at intervals of $0-60$ minutes until the absorbance is obtained stable. $^{10}$

\subsubsection{Determination of the standard curve of quercetin}

The 100 ppm quercetin solution was made in series with concentrations of 20,40 , 60,80 and $100 \mathrm{ppm}, 1 \mathrm{~mL}$ of each concentration was taken into a volumetric flask, added $1 \mathrm{~mL}$ of $10 \% \mathrm{AlCl}_{3}$ and $8 \mathrm{~mL}$ of $5 \%$ acetic acid, allowed to stand for the optimum time, then 
Absorbance readings were carried out using a UV-Vis spectrophotometer at the maximum wavelength. ${ }^{10}$

\subsubsection{Determination of total flavonoids}

The ethanol extract $70 \%$, ethanol $96 \%$ and the ethyl acetate fraction of Moringa leaves were weighed as much as $100 \mathrm{mg}$ and added $100 \mathrm{ml}$ of each solvent concentration of ethanol (1000 ppm concentration), then taken $1,0 \mathrm{~mL}$ and added $1,0 \mathrm{ml}$ of $10 \% \mathrm{AlCl}_{3}$ and acid $8 \mathrm{~mL}$ of $5 \%$ acetate, vortexed and allowed to stand for the optimum time and read the absorbance at the maximum wavelength and repeated 3 times. ${ }^{10}$

\subsection{Research data analysis}

The flavonoid content was calculated by measuring $70 \%$ ethanol extract, $96 \%$ ethanol and the ethyl acetate fraction of Moringa leaves (Moringa oleifera L.) and then calculated using the linear regression equation $(y=a+b x) .{ }^{10}$ The statistical test using the LSD (Least Significance Different) test was used to test the average difference between the 3 treatment groups using SPSS 16th Edition software, so this test was used to determine the significant difference in total flavonoid levels between samples of $70 \%$ ethanol extract, $96 \%$ ethanol and ethyl acetate fraction of Moringa leaf. ${ }^{10}$

\section{Result}

3.1. Moringa leaf simplicia microscopic identification

Microscopic examination of

Moringa leaf powder aims to determine the characteristics of leaf identification fragments using a microscope. The chloral hydrate solution aims to remove cell content such as protein and starch, so that the cell identification fragments on the leaves can be clearly observed with a microscope. ${ }^{12}$ Table 1 informs the microscopic results of Moringa leaf simplicia, showing that the presence of calcium oxalate crystals in the form of rosettes, mesophyll and stomata is in accordance with previous research and the Indonesian Herbal Pharmacopoeia Edition II (2017). ${ }^{13}$

\subsection{Extract yield and ethyl acetate fraction} The yield of Moringa leaf ethanol thick extract (EEDK) and Moringa leaf ethyl acetate fraction (FEDK) is shown in Table 2. Based on the Indonesian Herbal Pharmacopoeia Edition II, the yield of Moringa leaf thick

Table 1. Moringa Leaf Simplicia Powder Fragment (Moringa oleifera L)

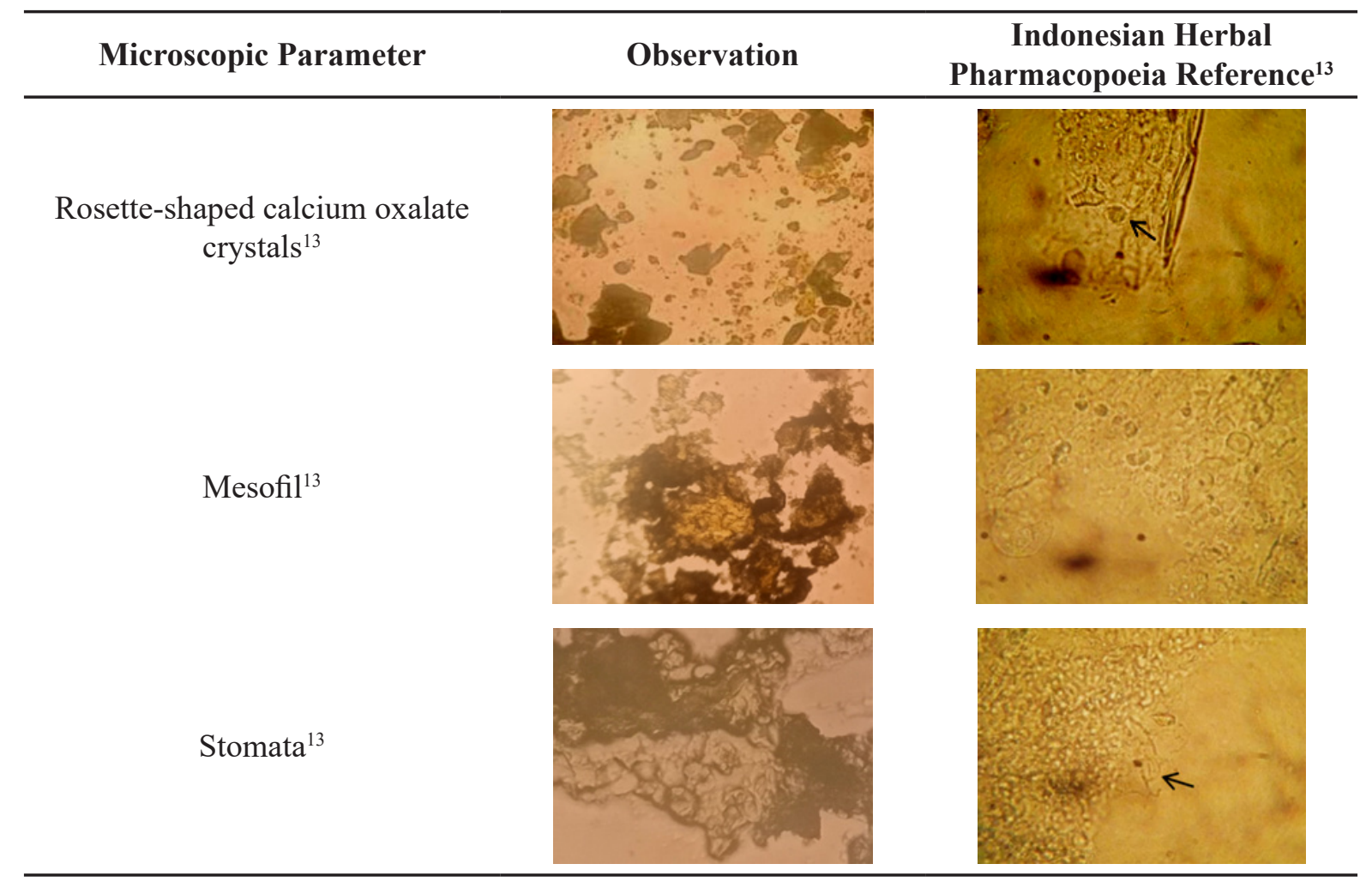


Table 2. Calculation of Moringa Leaf Extract and Fraction Yield

\begin{tabular}{ccc}
\hline Method & Thick Extract & Rendemen \\
\hline Maceration & Moringa Leaf Ethanol Extract 70\% (MLEE 70\%) & $16.09 \%$ \\
Maceration & Moringa Leaf Ethanol Extract 96\% (MLEE 96\%) & $23.80 \%$ \\
Fractionation & Moringa Leaf Ethyl Acetate Fraction (EFML) & $17.89 \%$ \\
\hline
\end{tabular}

extract is not less than $9.2 \%$ so that all extracts obtained meet the requirements. ${ }^{13}$

3.3. Phytochemical screening moringa leaf extract and ethyl acetate fraction

After obtaining the extract, phytochemical screening was carried out to determine the class of secondary metabolite compounds in the extract. This method is a qualitative analysis of the chemical compounds contained in the Moringa leaf plant. The screening tests carried out were flavonoids, alkaloids, saponins and tanins because this test already represented several groups of compounds contained in the Moringa leaf plant. The results showed that the ethanol extract of Moringa leaves was positive for flavonoids, alkaloids, saponins and tanins as shown in Table 3. ${ }^{9}$

3.4. Determination of total flavonoid content of Moringa leaf extract and ethyl acetate fraction

Analysis of the total flavonoid content in this study was carried out using a standard solution of quercetin in Table 4 . The readings were carried out at a wavelength of $413.15 \mathrm{~nm}$ with an operating time of 30 minutes according to previous studies. ${ }^{10}$ The determination of quercetin maximum wavelength shown in Figure 2. Determination of operating time in this study aims to determine the reaction time of flavonoid compounds with $\mathrm{AlCl}_{3}$ can react perfectly so that it is optimum

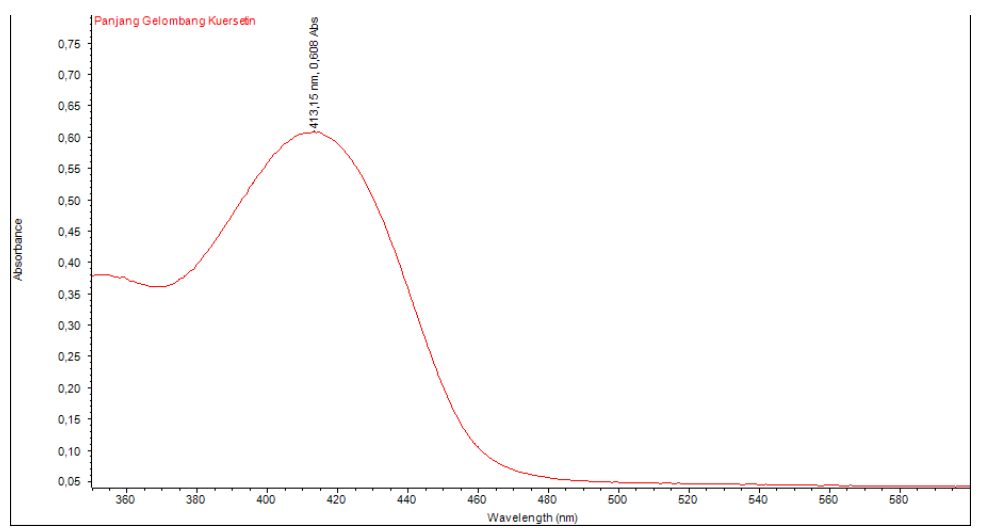

Figure 2. Determination of Quercetin Wavelength in Determination of Total Flavonoid Levels

Table 3. Phytochemical Screening Moringa Leaf Extract and Ethyl Acetate Fraction

\begin{tabular}{|c|c|c|c|c|c|}
\hline Screening & MLEE $70 \%$ & MLEE $96 \%$ & $E F M L$ & Treatment & Results \\
\hline Flavonoid & + & + & + & Ammonia Vapor & $\begin{array}{c}\text { Intensive } \\
\text { Yellow }\end{array}$ \\
\hline Saponin & + & + & + & Shaking & $\begin{array}{c}\text { Stable Foam } 30 \\
\text { second }\end{array}$ \\
\hline Tanin & + & + & + & $\mathrm{FeCl} 31 \%$ & $\begin{array}{c}\text { Formed } \\
\text { blackish green } \\
\text { color }\end{array}$ \\
\hline Alkaloid & + & + & + & Mayer & Sediment \\
\hline
\end{tabular}


when the absorption is read with Visible Spectrophotometry. ${ }^{10}$ Figure 3 showed the standard curved of quercetin.

The results of the total flavonoid content shown in Table 5 resulted in the highest flavonoid content value in $96 \%$ ethanol extract of Moringa leaves compared to $70 \%$ ethanol extract and ethanol fraction of Moringa leaves. The flavonoid content obtained for the ethanol extract of Moringa leaves is $70 \%$, ethanolic extract is $96 \%$ and the ethanol fraction of Moringa leaves is $10.84 \% ; 16.69 \%$ and $14.15 \%$. This shows that the flavonoid components contained in MLEE 70\%, MLEE 96\% and the ethyl acetate fraction of the $70 \%$ ethanol extract of Moringa leaves (EFML) can be said to be quite high and have the potential to be developed and explored further related to biological activity, especially as an antioxidant. ${ }^{6}$

Moringa leaf plants have the characteristics of an oval shape with all parts of the same width, the upper part of the leaf is light green, the edges are split, the underside of the leaves is rounded, the leaf edges are flat, the leaf surface is rough and the leaf spines are pinnate. The cross-sectional sections of the leaves consisted of the lower epidermis, bundle vessels, collenchyma, spongy tissue, upper epidermis and palisade. ${ }^{13}$ Maceration is an extraction method that is carried out by immersing simplicia powder using a solvent that is suitable for the immersion process, stirring to extract a certain substance. The solvents used in this study were $70 \%$ and $96 \%$ ethanol. Ethanol is a solvent that is polar, non-toxic and has the advantage of being able to extract more chemical compounds than methanol and water. ${ }^{14}$ The choice of solvent used is based on the nature of the compound to be taken (like dissolves like), meaning that if the compound to be taken is polar, the solvent used must be polar so that the active substance will be completely dissolved into the solvent. ${ }^{15}$

According to research by Siluh et al., (2015) previously stated that phenolic compounds, namely flavonoids, can be completely dissolved in ethanol solvent16. The stirring process in the maceration method aims to take a certain substance by breaking the walls and cell membranes due to the difference in pressure outside and inside the cell. ${ }^{17}$ The use of solvents with different

Table 4. Quercetin Standard Curve for Determination of Total Flavonoid Level

\begin{tabular}{cc}
\hline Quercetin standard (ppm) & Absorbance \\
\hline 20 & 0.173 \\
40 & 0.281 \\
60 & 0.401 \\
80 & 0.534 \\
100 & 0.655 \\
\hline
\end{tabular}

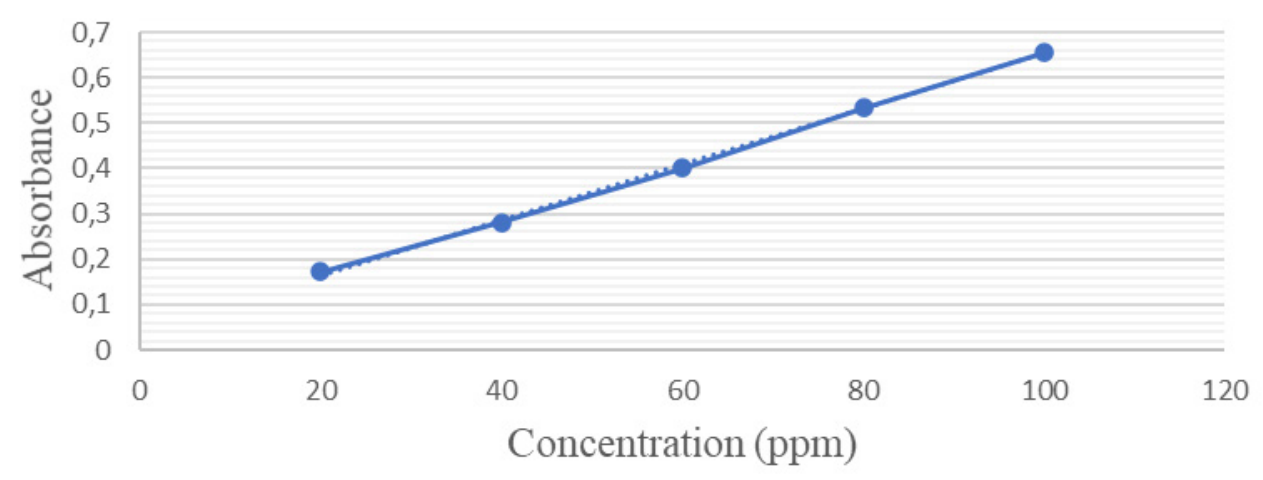

Figure 3. Curve of Quercetin Standard Linear Regression Equation on Determination of Total Flavonoid Level 
Table 5. Results of Determination of Total Flavonoid Levels of MLEE and EFML

\begin{tabular}{|c|c|c|c|}
\hline Sample & Replication & $\begin{array}{r}\text { Flavonoid Total } \\
(\% \mathrm{~b} / \mathbf{b})\end{array}$ & $\begin{array}{l}\mathrm{X} \pm \mathrm{SD} \\
(\% \mathrm{~b} / \mathbf{b})\end{array}$ \\
\hline \multirow[t]{3}{*}{ MLEE $70 \%$} & 1 & 10.60 & $10.84 \pm 0.49$ \\
\hline & 2 & 10.84 & \\
\hline & 3 & 11.09 & \\
\hline \multirow[t]{3}{*}{ MLEE $96 \%$} & 1 & 16.66 & $16.69 \pm 0.74$ \\
\hline & 2 & 16.34 & \\
\hline & 3 & 17.07 & \\
\hline \multirow[t]{3}{*}{ EFML } & 1 & 13.63 & $14.15 \pm 0.90$ \\
\hline & 2 & 14.45 & \\
\hline & 3 & 14.37 & \\
\hline
\end{tabular}

concentrations is carried out to determine differences in the acquisition of secondary metabolite content in the extract because the higher the concentration of a solution, the more active substances will be extracted so that the percent yield value of the extract will be greater. ${ }^{18}$ Concentration of the filtrate using a vacuum rotary evaporator for 1 hour at a temperature of $60^{\circ} \mathrm{C}$ at a speed of $100 \mathrm{rpm}$ produces a thick extract which will be tested further. Calculation of the yield of a sample is related to the active compounds contained in the extract so that the greater the yield value, the more active compounds are taken. ${ }^{19}$

Figure 3, the curve shows that the higher the concentration of the solution, the higher the absorbance value obtained, with the linear regression equation $\mathrm{y}=0.0061 \mathrm{x}+0.0437$ and the value of $\mathrm{R}=0.9999$. The calculated $\mathrm{R}$ value $>\mathrm{R}$ table $=0.8783$ (degrees of freedom $3 ; p<0.05$ ), so the linear regression equation can be used to calculate the total flavonoid content in this study. ${ }^{20}$ The limit of detection (LOD) value is $0.461 \mathrm{ppm}$ and the limit of quantification (LOQ) value is $1.396 \mathrm{ppm}$. The limit of detection (LOD) states the smallest amount of analyte in the sample that can be detected that still gives a significant response compared to the blank. While the limit of quantization (LOQ) is the smallest amount of analyte in the sample that still meets the criteria carefully and thoroughly and can be quantified with good accuracy and precision. ${ }^{21}$

Determination of total flavonoid levels with standard compounds of quercetin added with $\mathrm{AlCl}_{3}$, resulting in the complex compounds shown in Figure 1. This test was carried out using UV-Vis spectrophotometry with the principle of complex compound formation reactions, in which there was a shift in the reading of visible light waves marked by the color of the solution. yellower and the addition of acetic acid to maintain the wavelength in the visible light region. ${ }^{10}$ The carbonyl hydroxy group contained in flavonoid compounds will react with $\mathrm{AlCl}_{3}$ to form complex compounds. ${ }^{8}$ The hydroxyl group $(-\mathrm{OH})$ in flavonoids, in particular almost always located on ring $\mathrm{B}$ at the $3^{\prime}$ and 4' positions, can also react with $\mathrm{AlCl}_{3}$ to form flavonoid-aluminum complexes. This research can be an informative basis that the flavonoid group in Moringa leaves plays a role in producing medicinal raw materials derived from natural ingredients with standardized levels of identity compounds. ${ }^{\text {? }}$

\section{Conclusion}

The highest total flavonoid content was found in the $96 \%$ ethanol extract of Moringa leaves $(16.69 \pm 0.74 \% \mathrm{w} / \mathrm{w})$ in accordance with the 2017 Indonesian Herbal Pharmacopoeia, that the thick extract of Moringa leaves contained no less than $6.30 \%$ $(\mathrm{w} / \mathrm{w})$ total flavonoids calculated as quercetin.

\section{Acknowledgement}

The author would like to thank the APTFI (Asosiasi Perguruan Tinggi Farmasi Indonesia), Indonesian Ministry of Higher Education (Kemenristek DIKTI), LL Dikti Region V, Alma Ata University, Tim Research 
Moringa Leaf and all participant that we can't mention one by one.

\section{References}

1. Sugihartini N, Nuryanti E. Formulasi Krim Ekstrak Daun Kelor (Moringa oleifera) sebagai Sediaan Antiaging. Berkala Ilmu Kesehatan Kulit Dan Kelamin. 2017;29(1):1-7.

2. Fatmawati A, Bachri MS, Nurani LH. Combination Effects of Moringa oleifera Leaf Ethanol Extract and Andrographis paniculata Herb on Blood Glucose Levels and Pancreas Histopathology of Diabetic Rats Induced by Streptozotocin. Majalah Obat Tradisional.;24(2) 2019 :85-90.

3. Abidin Z, Khaeriah U, Zuhrina Z, Pratama M, Baits M. Tyrosinase Inhibitor Activity Measurement of Crude and Purified Extract of Moringa Leaves (Moringa oleifera L.). Indonesian Journal of Pharmaceutical Science and Technology. 2019 Mar 31;1(1):52-8.

4. Ilanko P, McDonnell PA, van Vuuren $\mathrm{S}$, Cock IE. Interactive antibacterial profile of Moringa oleifera Lam. extracts and conventional antibiotics against bacterial triggers of some autoimmune inflammatory diseases. South African Journal of Botany. 2019 Aug 1;124:42035.

5. Saleem A, Saleem M, Akhtar MF, Shahzad M, Jahan S. Moringa rivae leaf extracts attenuate Complete Freund's adjuvant-induced arthritis in Wistar rats via modulation of inflammatory and oxidative stress biomarkers. Inflammopharmacology. $2020 \mathrm{Feb} ; 28(1)$ : 139-51.

6. Hasanah N, Susilo J, Oktianti D. Uji Aktivitas Antioksidan Ekstrak Etanol Daun Kelor (Moringa oleifera Lamk) dengan Metode DPPH. Jurnal Gizi dan Kesehatan. 2017 May 24;9(21):97-102.

7. Pambudi A, Syaefudin S, Noriko N, Azhari R, Azura PR. Identifikasi Bioaktif Golongan Flavonoid Tanaman AntingAnting (Acalypha indica L.). Jurnal AlAzhar Indonesia Seri Sains dan Teknologi. 2015 Nov 2;2(3):178-87.
8. Ramadhan H, Rezky DP, Susiani EF. Penetapan Kandungan Total FenolikFlavonoid pada Fraksi Etil Asetat Kulit Batang Kasturi (Mangifera casturi Kosterman). JURNAL FARMASI DAN ILMU KEFARMASIAN INDONESIA. 2021 Apr 27;8(1):58-67.

9. Reubun YT, Kumala S, Setyahadi S, Simanjuntak P. Freezed Drying of Kelor Leaves Extract (Moringa oleifera Lam.). Jurnal Sains dan Kesehatan. 2021 Aug 31;3(4):470-4.

10. Asmorowati $\mathrm{H}$ dan Lindawati NY. Penetapan kadar flavonoid total buah alpukat biasa (Persea americana Mill.) dan alpukat mentega (Persea americana Mill.) dengan metode spektrofotometri UV-Vis. Jurnal Ilmiah Farmasi. 2019 Nov 28;15(2):51-63

11. Sulistyawati R, Nurani LH, Hidayati S, Mursyidi A, Mustofa M. Standarisasi kualitas fraksi etil asetat daun kelor (Moringa oleifera lamk.). URECOL. 2017 Sep 6:67-72.

12. Supomo, Supriningrum R, Junaid R. Karakterisasi Dan Skrining Fitokimia Daun Kerehau (Callicarpa longifolia Lamk.). Jurnal Kimia Mulawarman. 2016 Jun 13;13(2).

13. Departemen Kesehatan Republik Indonesia, 2017, Farmakope Herbal Indonesia Edisi Kedua,. 209 -213, Departemen Kesehatan Republik Indonesia, Jakarta

14. Riwanti P, Izazih F, Hang U, Surabaya T, Indonesia S, Total F. Pengaruh Perbedaan Konsentrasi Etanol pada Kadar Flavonoid Total Ekstrak Etanol 50,70 dan 96\%. 2020. 2(2):82-95.

15. Sarastani D, Soekarto ST, Muchtadi TR, Fardiaz D, Apriyantono A. Aktivitas Antioksidan Ekstrak Dan Fraksi Ekstrak Biji Atung (Parinarium Glaberrimum Hassk.) 1) [Antioxidant Activities of Parinarium glaberrimum Hassk Extracts and their Fractions] Bahan dan Alat Metode. 2002; XIII(2).

16. Siluh Putu Sri D, Nurjanah A, Mardiono J. Komposisi kimia dan aktivitas antioksidan akar, kulit batang dan daun 
lindur. 2015;18.

17. Deny Romadhon Badaring, Sari Puspitha Mulya Sari, Satrina Nurhabiba, Wirda Wulan SARL. Uji Ekstrak Daun Maja (Aegle mamerlos L.) Terhadap Pertumbuhan Bakteri Escheria coli dan Staphylococcus aerus. 2020;6(1):16-26.

18. Do QD, Angkawijaya AE, Tran-Nguyen PL, Huynh LH, Soetaredjo FE, Ismadji S, et al. Effect of extraction solvent on total phenol content, total flavonoid content, and antioxidant activity of Limnophila aromatica. J Food Drug Anal [Internet]. 2014;22(3):296-302.

19. Hasnaeni, Wisdawati SU. Pengaruh Metode Ekstraksi Terhadap Rendemen Dan Kadar Fenolik Ekstrak Tanaman Kayu Beta-Beta (Lunasia amara Blanco). J Farm Galen (Galenika J Pharmacy). 2019;5(2):166-74.

20. Fatmawati, Annisa dan Nurwani Purnama Aji. 2019. Penetapan Kadar Flavonoid Total Ekstrak Etanol Daun Kelor (Moringa oleifera Lam) Dengan Metode Kromatografi Lapis Tipis Densitometri. Published online 2019: 1-7. http://fikes.almaata.ac.id/ wp-content/uploads/2019/07/AnnisaatmawatiNurwani-Purnama-Aji.pdf.

21. Hadisoebroto, Ginayati, dan Senadi Budiman. 2019. Penetapan Kadar Asam Salisilat pada Krim Anti Jerawat yang Beredar di Kota Bandung dengan Metode Spektrotometri Ultra Violet. J. Kartika Kimia, Mei 2019, 2, (1), 51-56. 